\title{
Breast Cancer pT4d TNM Finding v8
}

National Cancer Institute

\section{Source}

National Cancer Institute. Breast Cancer pT 4d TNM Finding v8. NCI Thesaurus. Code C139427.

Breast cancer meeting the criteria of inflammatory carcinoma. (from AJCC 8th Ed.) 